\title{
Updates on the genetic variations of Norovirus in sporadic gastroenteritis in Chungnam Korea, 2009-2010
}

\author{
KwiSung Park', SangGu Yeo², HyeSook Jeong ${ }^{2}$, KyoungAh Baek', DongUk Kim¹, MyoungHee Shin', \\ JaeHyoung Song ${ }^{3}$, SooJin Lee ${ }^{4}$, YoungJin Choi ${ }^{5}$, JoonSoo Park ${ }^{6}$, SungChan Cho ${ }^{3^{*}}$ and DooSung Cheon ${ }^{2^{*}}$
}

\begin{abstract}
Previously, we explored the epidemic pattern and molecular characterization of noroviruses (Novs) isolated in Chungnam, Korea in 2008, and the present study extended these observations to 2009 and 2010. In Korea, NoVs showed the seasonal prevalence from late fall to spring, and widely detected in preschool children and peoples over 60 years of age. Epidemiological pattern of NoV was similar in 2008 and in 2010, but pattern in 2009 was affected by pandemic influenza A/H1N1 2009 virus. NoV-positive samples were subjected to sequence determination of the capsid gene region, which resolved the isolated NoVs into five GI $(2,6,7,9$ and 10) and eleven Gll genotypes $(1,2,3,4,6,7,8,12,13,16$ and 17). The most prevalent genotype was Gll.4 and occupied 130 out of $211 \mathrm{NoV}$ isolates (61.6\%). Comparison of NoV Gll.4 of prevalent genotype in these periods with reference strains of the same genotype was conducted to genetic analysis by a phylogenetic tree. The NoV Gll.4 strains were segregated into seven distinct genetic groups, which are supported by high bootstrap values and previously reported clusters. All Korean NoV GII.4 strains belonged to either VI cluster or VII cluster. The divergence of nucleotide sequences within VI and VII intra-clusters was $>3.9 \%$ and $>3.5 \%$, respectively. The "Chungnam(06117)/2010" strain which was isolated in June 2010 was a variant that did not belong to cluster VI or VII and showed $5.8-8.2 \%, 6.2-8.1 \%$ nucleotide divergence with cluster VI and VII, respectively.
\end{abstract}

\section{Background}

The noroviruses (NoVs) are classified in the genus Norovirus within the family Caliciviridae and are now considered the most important cause of outbreaks and sporadic cases of non-bacterial gastroenteritis worldwide [1]. Patients who are infected by NoVs usually show gastrointestinal manifestations including diarrhea, vomiting, abdominal pain, and low grade fever, and almost all of the infected cases resolve spontaneously [2]. NoV strains exhibit wide genetic diversity, and both genogroup GI and GII and different genotypes within the genogroups

\footnotetext{
* Correspondence: sungchan@kribb.re.kr; cheonds@hanmail.net ${ }^{2}$ Division of Enteric and Hepatitis Viruses, Center for Infectious Diseases, National Institute of Health, Korea Center for Disease Control and Prevention, 187 Osongsaengmyeong2(i)-ro, Gangoe-myeon, Cheongwon-gun, Chungcheongbuk-do, Korea

${ }^{3}$ Bio-Therapeutics Research Institute, Korea Research Institute of Bioscience and Biotechnology, 685-2 Yangcheong-ri, Ochang-eup, Cheongwon-gun, Chungcheongbuk-do 363-883, Korea

Full list of author information is available at the end of the article
}

cocirculate in a given geographical region at the same time [3].

$\mathrm{NoV}$ is a small round virion containing a singlestranded, positive-sense, 7.4-7.7 kb polyadenylated RNA genome, and 27-35 $\mathrm{nm}$ in diameter. The viral genome encodes three open reading frames (ORFs): ORF1, ORF2, and ORF3 [4-6]. Genetically, NoVs have been classified into five major groups: GI to GV. GI, GII, and GIV generally infect humans; GIII and GV infect bovine and murine species, respectively. GI, GII, and GIII have been subdivided into 14, 17, and 2 genetic clusters, respectively, whereas both GIV and GV have only one cluster $[7,8]$.

Seeing the high variability of NoV seasonality, it seems to be other factors govern transmission pattern of disease except environmental factors. Immunity to NoV infection and disease is generally temporal and heterotypic protection is limited [9]. Additionally, NoVs are highly infectious. Due to these combined factors, nearly

\section{Biomed Central}


all children will have had at least once NoV infection by their fifth birthday. However infections and disease occur throughout life as immunity wanes and new antigenic types are encountered [10]. Indeed, NoVs are constantly evolving, with the most common group of viruses (GII.4) under positive selection pressure-whereby immune escaping variants are selected for [11]. New variants with antigenic changes may escape population immunity. The emergence of such variants has been shown to be associated with substantial increases in cases worldwide [12,13]. Therefore, understanding of molecular epidemiology of NoV is very important. This study was to determine the epidemiology of NoV infection and molecular characteristics of Korean NoV GII.4 isolates.

\section{Materials and methods Stool specimens}

It was collected a total of 3171 stool specimens from patients with acute gastroenteritis in Chungnam, Korea from 2009 to 2010. The fecal specimens were diluted with phosphate buffered saline to $10 \%$ suspensions, and clarified by centrifugation at 8,000X $\mathrm{g}$ for $15 \mathrm{~min}$.

\section{RNA extraction and Detection of NoV in clinical samples}

The viral RNA was extracted from the faecal supernatant using Viral Nucleic Acid Prep Kit according to the manufacturer's instructions (Greenmate Biotech, Seoul, Korea). The extracted RNA was dissolved in $50 \mu \mathrm{L}$ of nuclease-free water and stored at $-80^{\circ} \mathrm{C}$ until use for real-time and semi-nested RT-PCR. Real-time RT PCR for NoV detection was conducted using an AccuPower Norovirus Real-Time RT-PCR Kit (Bioneer, Daejeon, Korea) in accordance with the manufacturer's instructions; the $50 \mu \mathrm{L}$ reaction mixtures contained $10 \mu \mathrm{L}$ of RNA and each primer at a final concentration of 0.3 $\mu \mathrm{M}$ [14]. Reactions were performed using Exicycler ${ }^{\mathrm{TM}} 96$ (Bioneer, Daejeon, Korea) under the following conditions: initial hold at $45^{\circ} \mathrm{C}$ for $15 \mathrm{~min}$ and $95^{\circ} \mathrm{C}$ for 5 min, followed by 45 cycles at $95^{\circ} \mathrm{C}$ for $5 \mathrm{sec}, 55^{\circ} \mathrm{C}$ for 5 sec, and $25^{\circ} \mathrm{C}$ for $1 \mathrm{~min}$. A sample with threshold cycle value $<35$ and a typical sigmoid curve was defined as positive.

\section{Nucleotide sequencing and molecular typing}

In an effort to identify NoV genotypes, it was performed direct sequencing of all samples that tested positive for NoV by the real-time RT-PCR assay. For sequencing, semi-nested RT-PCR was conducted as described previously $[12,15]$. Products from the semi-nested PCR were purified using a QIA quick PCR purification kit (Qiagen, Hilden, Germany). The purified DNA was added to a reaction mixture containing $2 \mu \mathrm{L}$ of BigDye Terminator reaction mix (ABI Prism Big Dye
Terminator cycle sequencing kit; Perkin-Elmer/Applied Biosystems, Waltham, CA, USA) and 2 pmol each of the GI-R1M and GII-R1M primers. Sequencing reactions were subjected to an initial denaturation at $96^{\circ} \mathrm{C}$ for 1 min, followed by 25 cycles of $96^{\circ} \mathrm{C}$ for $10 \mathrm{sec}, 50^{\circ} \mathrm{C}$ for 5 sec, and $60^{\circ} \mathrm{C}$ for $4 \mathrm{~min}$ in a thermal cycler (Gene Amp PCR System 2700; Perkin-Elmer/Applied Biosystems, Waltham, CA, USA). The products were purified by precipitating them with $100 \%$ cold ethanol, $3 \mathrm{M}$ sodium-acetate ( $\mathrm{pH} 5.8$ ) before being loaded onto an automated analyzer (3730 XL DNA Analyzer; PerkinElmer/Applied Biosystems, Waltham, CA, USA). A BLAST search of GenBank sequences was conducted to determine the molecular type of each isolate. This was defined as the genotype that was scored as having the most nucleotides in common with the query sequence [16].

\section{Phylogenetic analysis}

Nucleotide sequences of Korean 31 candidate NoV isolates were compared with the 20 reference sequences using Clustal W v. 2.1 [17]. Phylogenetic relationships among the ORF2 sequences of the virus isolates were determined using MEGA software v. 5.05. Maximum Composite Likelihood was used as the substitution method, while the neighbor-joining method was used to reconstruct the phylogenetic tree $[18,19]$. The reliability of the phylogenetic tree was determined by bootstrap re-sampling of 1,000 replicates.

\section{Nucleotide sequence accession numbers}

The NoV candidate sequences were deposited in the GenBank sequence database (accession numbers JN688175 to JN688204).

\section{Results}

\section{Epidemiological features and genotyping of NoVs}

We previously reported the results for epidemiological study of NoVs in Chungnam, Korea in 2008 [15]. The current study extended these findings by investigating the difference of the epidemic patterns in 2009 and 2010. In this period, 3171 samples obtained from patients with acute gastroenteritis were diagnosed for NoVs using by real-time RT-PCR and NoV positive samples were analyzed to sequences in capsid region. Consequently, it was detected a total of 211 NoVs: 64 from 1479 cases (4.3\%) in 2009, and 147 from 1692 cases (8.7\%) in 2010. Out of the total 211 cases, 5 cases (2.4\%) were identified as GI genogroup and 206 cases $(97.6 \%)$ as GII genogroup, which were further resolved into $5 \mathrm{GI}$ and 11 GII genotypes, respectively. In decreasing order of abundance, these were: GII.4 ( $\mathrm{n}=130$, 64.0\%), GII.3 ( $\mathrm{n}=24,11.8 \%)$, GII.8 ( $\mathrm{n}=16,7.9 \%)$, GII.1 ( $\mathrm{n}=10,4.9 \%)$, GII.2 and GII.7 $(\mathrm{n}=7,3.4 \%)$, and GII.12 
Table 1 Number of NoV genotypes isolated in Chungnam, Korea, from 2009 to 2010

\begin{tabular}{|c|c|c|c|c|c|}
\hline \multirow{2}{*}{$\begin{array}{l}\text { Genotype } \\
\text { of NoV }\end{array}$} & & \multicolumn{2}{|l|}{2009} & \multicolumn{2}{|l|}{2010} \\
\hline & & Numbers of $\mathrm{NoV}$ & Percentage of subtotal & Numbers of NoV & Percentage of subtotal \\
\hline \multirow[t]{5}{*}{ Gl } & $\mathrm{Gl} .2$ & - & 0.0 & 2 & 0.9 \\
\hline & Gl.6 & - & 0.0 & 2 & 0.9 \\
\hline & $\mathrm{Gl} .7$ & - & 0.0 & 2 & 0.9 \\
\hline & $\mathrm{Gl} .9$ & - & 0.0 & 1 & 0.5 \\
\hline & Gl.10 & - & 0.0 & 1 & 0.5 \\
\hline \multirow[t]{11}{*}{ Gll } & Gll.1 & 1 & 1.6 & 9 & 6.1 \\
\hline & Gll.2 & 5 & 7.8 & 2 & 1.4 \\
\hline & Gll.3 & 5 & 7.8 & 19 & 12.9 \\
\hline & GIl.4 & 39 & 60.9 & 91 & 61.9 \\
\hline & Gll.6 & - & 0.0 & 1 & 0.7 \\
\hline & Gll.7 & 1 & 1.6 & 6 & 4.1 \\
\hline & Gll.8 & 9 & 14.1 & 7 & 4.8 \\
\hline & Gll.12 & 1 & 1.6 & 2 & 1.4 \\
\hline & Gll.13 & 1 & 1.6 & - & 0.0 \\
\hline & Gll.16 & 1 & 1.6 & 2 & 1.4 \\
\hline & Gll.17 & 1 & 1.6 & - & 0.0 \\
\hline Total & & 64 & 100 & 147 & 100 \\
\hline
\end{tabular}

and GII.16 ( $\mathrm{n}=3,1.5 \%)$. The other thirteen genotypes (GII.6, GII.13, GII.17 and all GIs) were responsible for the remaining $1.0 \%$ of cases (Table 1 ). The highest occurrence of GII.4 genotype has been reported in many recent surveillance of NoV epidemic throughout world [20], which is similar to our observation with Korean $\mathrm{NoV}$ isolates. Temporal distribution of the NoV epidemic in Chungnam Korea was seasonal, with most cases occurred during the winter from November to April (Figure 1). The high NoV detection rate in age distribution was $19.5 \%, 4.7 \%$, and $15.4 \%$ in preschool age (under 5 ages), $12.3 \%, 4.3 \%$, and $8.7 \%$ in old adult group (over 60 ages), from 2008 to 2010, respectively (Table 2). The 122 were from males and 89 were from

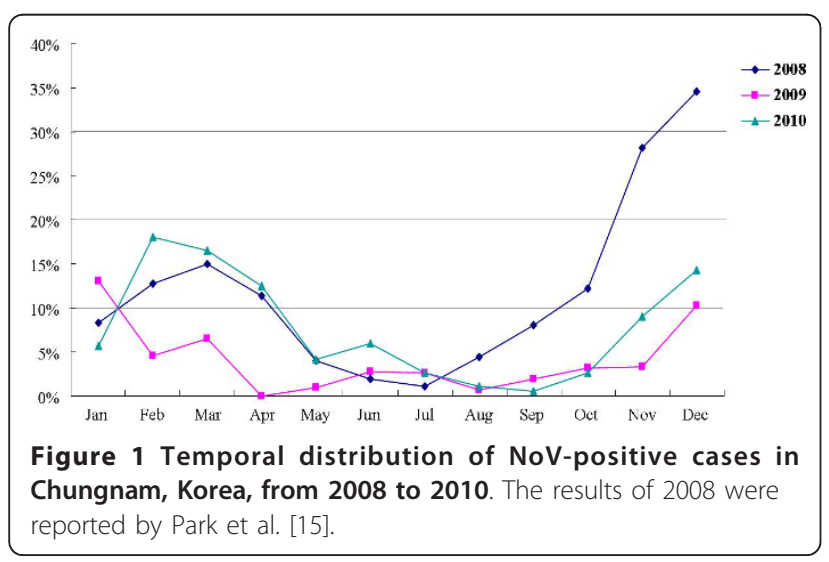

females, giving a male-to-female ratio of approximately 1.37:1.

\section{Phylogenetic analysis of GII.4}

The partial nucleotide sequences of ORF2 of 30 randomly selected NoV GII.4 strains obtained from patients with acute gastroenteritis (from 2008 to 2010) were used to construct a phylogenetic tree with 20 reference strains of the same genotype extracted from GenBank database. The NoV GII.4 strains were segregated into seven distinct genetic groups, which were supported by high bootstrap values and previously reported clusters including (I) CHDC cluster (1970s)[20], (II) Camberwell cluster (1987-1995) [21], (III) Grimsby cluster (19952002) [22], (IV) Farmington Hills cluster (2002-2004) [2,11,23], (V) Hunter cluster (2002-2004) [24], (VI) Sakai \& 2008-Korea_a cluster (2004-2008) [8,15,22], and (VII) 2008-Korea_b cluster (2008) [15]. As expected, all analyzed strains belonged to one of two previously defined Korean types of clusters, (VI) Sakai \& 2008-Korea_a cluster and (VII) 2008-Korea_b cluster. The divergence of nucleotide sequence within (VI) Sakai \& 2008Korea_a intra-cluster and (VII) 2008-Korea_b intra-cluster was $>3.9 \%$ and $>3.5 \%$, respectively. The (VI) Sakai $\&$ 2008-Korea_a cluster showed 8.6-11.7\%, 5.3-7.7\%, 3.5$6.3 \%, 3.9-5.4 \%$, and $2.2-4.4 \%$ nucleotide divergence from cluster I to cluster V, respectively. The (VII) 2008-Korea_b cluster showed 7.7-10.6\%, 4.4-6.7\%, 1.7-6.2\%, 2.2$5.3 \%, 3.0-8.1 \%$ nucleotide divergence from cluster I to VI, respectively. The "Chungnam(06-117)/2010 
Table 2 Age distribution of NoV positive patients in Chungnam, Korea, from 2008 to 2010

\begin{tabular}{|c|c|c|c|c|c|c|c|c|c|c|c|c|}
\hline & \multicolumn{2}{|c|}{$\begin{array}{c}<5 \\
\text { (Preschool age) }\end{array}$} & \multicolumn{2}{|c|}{$\begin{array}{c}6-20 \\
\text { (School age) }\end{array}$} & \multicolumn{2}{|c|}{$\begin{array}{c}21-40 \\
\text { (Young adult) }\end{array}$} & \multicolumn{2}{|c|}{$\begin{array}{c}41-60 \\
\text { (Middle adult) }\end{array}$} & \multicolumn{2}{|c|}{$\begin{array}{c}>60 \\
\text { (Old adult) }\end{array}$} & \multicolumn{2}{|c|}{ Total } \\
\hline & Sample no. & $\begin{array}{l}\text { Positive no. } \\
\text { (Percentage) }\end{array}$ & Sample no. & $\begin{array}{l}\text { Positive no. } \\
\text { (Percentage) }\end{array}$ & Sample no. & $\begin{array}{l}\text { Positive no. } \\
\text { (Percentage) }\end{array}$ & Sample no. & $\begin{array}{l}\text { Positive no. } \\
\text { (Percentage) }\end{array}$ & Sample no. & $\begin{array}{l}\text { Positive no. } \\
\text { (Percentage) }\end{array}$ & Sample no. & $\begin{array}{l}\text { Positive no. } \\
\text { (Percentage) }\end{array}$ \\
\hline 2008 & 687 & $\begin{array}{c}134 \\
(19.5 \%)\end{array}$ & 161 & $\begin{array}{c}11 \\
(6.8 \%)\end{array}$ & 81 & $\begin{array}{c}4 \\
(4.9 \%)\end{array}$ & 171 & $\begin{array}{c}10 \\
(5.8 \%)\end{array}$ & 368 & $\begin{array}{c}21 \\
(5.7 \%)\end{array}$ & 1,468 & $\begin{array}{c}180 \\
(12.3 \%)\end{array}$ \\
\hline 2009 & 760 & $\begin{array}{c}36 \\
(4.7 \%)\end{array}$ & 135 & $\begin{array}{c}6 \\
(4.4 \%)\end{array}$ & 67 & $\begin{array}{c}3 \\
(4.5 \%)\end{array}$ & 163 & $\begin{array}{c}8 \\
(4.9 \%)\end{array}$ & 354 & $\begin{array}{c}11 \\
(3.1 \%)\end{array}$ & 1,479 & $\begin{array}{c}64 \\
(4.3 \%)\end{array}$ \\
\hline 2010 & 810 & $\begin{array}{c}125 \\
(15.4 \%)\end{array}$ & 128 & $\begin{array}{c}5 \\
(3.9 \%)\end{array}$ & 110 & $\begin{array}{c}6 \\
(5.5 \%)\end{array}$ & 198 & $\begin{array}{c}2 \\
(1.0 \%)\end{array}$ & 446 & $\begin{array}{c}9 \\
(2.0 \%)\end{array}$ & 1,692 & $\begin{array}{c}147 \\
(8.7 \%)\end{array}$ \\
\hline Total & 2,257 & $\begin{array}{c}295 \\
(13.1 \%)\end{array}$ & 424 & $\begin{array}{c}22 \\
(5.2 \%)\end{array}$ & 258 & $\begin{array}{c}13 \\
(5.0 \%)\end{array}$ & 532 & $\begin{array}{c}20 \\
(3.8 \%)\end{array}$ & 1,168 & $\begin{array}{c}41 \\
(3.5 \%)\end{array}$ & 4,639 & $\begin{array}{c}391 \\
(8.4 \%)\end{array}$ \\
\hline
\end{tabular}

* The results of 2008 were reported by Park et al. [15] 
(JN688204)" strain which isolated in June 2010 was a variant that did not belong to cluster VI and showed 5.8-8.2\% nucleotide divergence from cluster VI (Figure 2).

\section{Discussion}

Global outbreaks of acute gastroenteritis by NoVs have been frequently reported since late 1990s, and NoV has been the etiological agent in many sporadic cases of gastroenteritis in Korea. We previously reported the epidemic occurrence of NoVs in Chungnam, Korea in 2008 [15]. The current study extended these findings by investigating the difference of the epidemic pattern in 2009 and 2010. Several studies in the past have demonstrated that NoV-associated gastroenteritis occurs mainly from late fall to spring [25-28]. Overall, the results of the present study are in accordance with this general pattern, except that epidemic of NoV in Chungnam Korea was temporarily reduced in the January during 2008 to 2010. The high NoV detection rate in age distribution was $19.5 \%, 4.7 \%$, and $15.4 \%$ in preschool

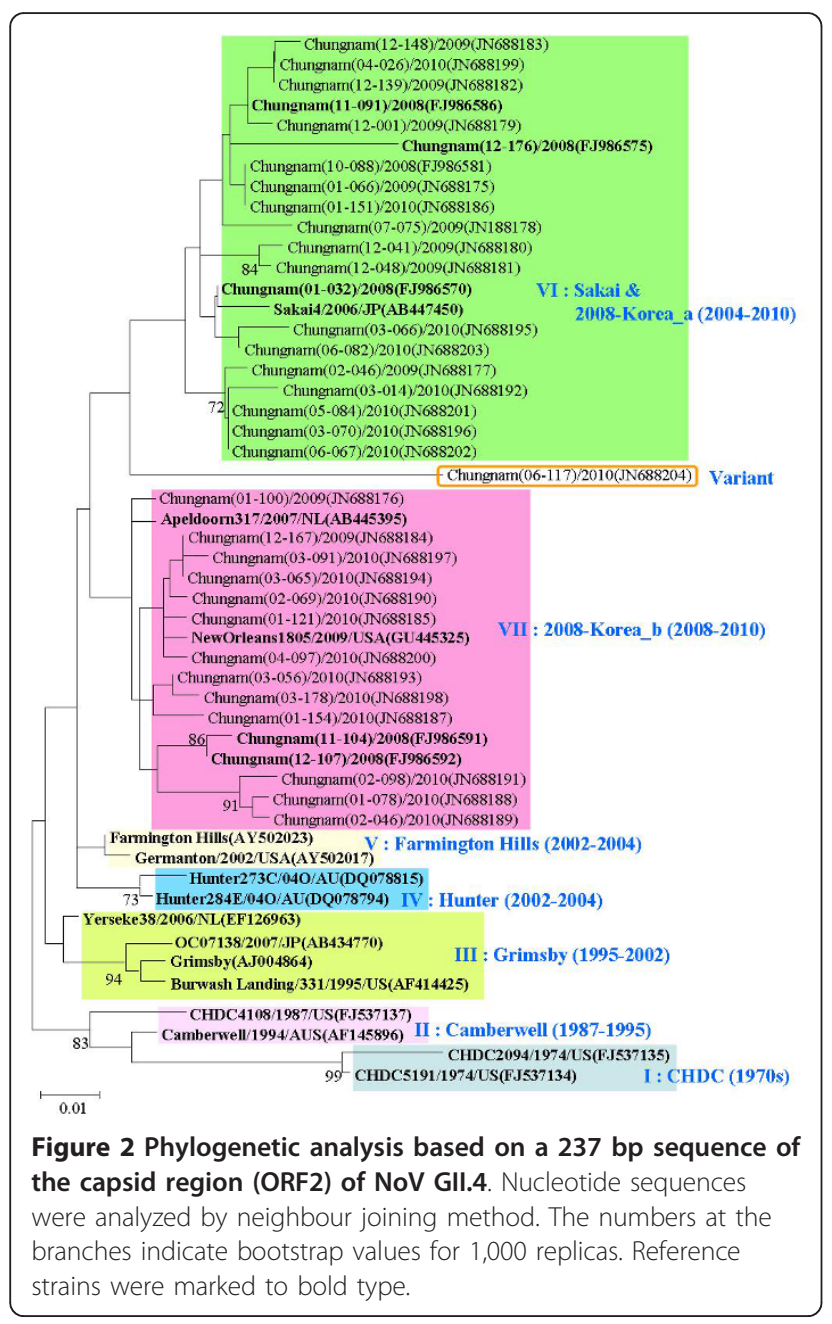

age (under 5 ages), $12.3 \%, 4.3 \%$, and $8.7 \%$ in old adult group (over 60 ages), from 2008 to 2010, respectively. Generally, the patterns of age distribution in 2008 and 2010 were similar but that of 2009 was different. The reason was considered to be aggressive hand-washing and reduction of social activities due to the pandemic H1N1 influenza in 2009.

This higher occurrence of NoV infection in young children and old people, who have weaker immunity than healthy adults, has been commonly observed. Immunity to NoV infection is temporal (between 2 and 6 months) and incomplete [9], and NoV infection frequently occurs and leads to symptoms even in adult groups unlike other viruses. In the present study, there were $5 \mathrm{GI}$ and $11 \mathrm{GII}$ genotypes identified. The highest prevalence of GII.4 NoV (61.6\%) is consistent with recent clinical molecular epidemiological studies $[20,24,29]$. The NoV GII.4 strains evolved and spread in a manner similar to that of influenza A virus, with a rapid global spread of emerging variant [25]. During the last decade, most epidemics of NoV infection have been associated with the emergence of several novel GII.4 variants: CHDC, Camberwell, Grimsby, Farmington Hills, Hunter, Sakai, more recently 2008-Korea_a and b [15,20-29]. In phylogenetic and diversity analysis, all Korean isolates analyzed in this study were contained into either cluster VI or VII which had been previously defined as the representative of Korean types of NoV. The divergence of nucleotide sequences of Korean isolates within cluster VI and VII was $>3.9 \%$ and $>3.5 \%$, respectively. The "Chungnam(06-117)/2010 (JN688204)" strain was a variant that did not belong to cluster VI or VII and showed 5.8-8.2\% and 6.2-8.1\% nucleotide divergence with cluster VI and VII, respectively. The RNA viruses have high mutation rate in general and new variants of GII.4 can emerge quickly $[13,15,30]$. In this study, it was analyzed epidemiological distribution of NoVs from acute gastroenteritis patients collected in Chungnam Korea from 2009 to 2010. It was suggested that the results of this study might reflect national trends of NoV epidemics in Korea, particularly over recent years. Molecular characterization of the Chungnam isolates also revealed patterns of variation that may be useful in future studies.

\section{Acknowledgements}

This study was supported by a grant from the Korea Healthcare Technology R\&D Project, Ministry for Health, Welfare \& Family Affairs, Republic of Korea (A085119).

\section{Author details}

'Chungcheongnam-Do Institute of Health and Environmental Research, Daejeon, Korea. ${ }^{2}$ Division of Enteric and Hepatitis Viruses, Center for Infectious Diseases, National Institute of Health, Korea Center for Disease Control and Prevention, 187 Osongsaengmyeong2(i)-ro, Gangoe-myeon, Cheongwon-gun, Chungcheongbuk-do, Korea. ${ }^{3}$ Bio-Therapeutics Research 
Institute, Korea Research Institute of Bioscience and Biotechnology, 685-2 Yangcheong-ri, Ochang-eup, Cheongwon-gun, Chungcheongbuk-do 363883, Korea. ${ }^{4}$ Department of Pediatrics, College of Medicine, Eulji University, Daejeon, Korea. ${ }^{5}$ Departments of Laboratory Medicine, College of Medicine, Soonchunhyang University, Cheonan, Korea. ${ }^{6}$ Departments of Pediatrics, College of Medicine, Soonchunhyang University, Cheonan, Korea.

\section{Authors' contributions}

KSP, SGY, HSJ, KAB, DUK, MHS, and JHS performed molecular diagnosis and sequence analysis. SJL, YJC, and JSP contributed to collection specimen and clinical diagnosis. SCC and DSC designed the study and critically revised the manuscript. All of the authors read and approved the final version of the manuscript.

\section{Competing interests}

The authors declare that they have no competing interests.

Received: 27 September 2011 Accepted: 24 January 2012 Published: 24 January 2012

\section{References}

1. Green KY, Ando T, Balayan MS, Berke T, Clarke IN, Estes MK, Matson DO, Nakata S, Neill JD, Studdert MJ, Thiel HJ: Taxonomy of the Caliciviruses. J Infect Dis 2000, 181:S322-S330.

2. Wilhelmi I, Roman E, Sánchez-Fauquier A: Viruses causing gastroenteritis. Clin Microbiol Infect 2003, 9(4):247-262.

3. Boga JA, Melón S, Nicieza I, De Diego I, Villar M, Parra F, De Oña M: Etiology of sporadic cases of pediatric acute gastroenteritis in Asturias, Spain and genotyping and characterization of norovirus strains involved. J Clin Microbiol 2004, 42:2668-2674.

4. Bull RA, Hansman GS, Clancy LE, Tanaka MM, Rawlinson WD, White PA: Norovirus recombination in ORF1/ORF2 overlap. Emerg Infect Dis 2005, 11(7):1079-1085.

5. Dove W, Cunliffe NA, Gondwe JS, Broadhead RL, Molyneux ME, Nakagomi O, Hart CA: Detection and characterization of human caliciviruses in hospitalized children with acute gastroenteritis in Blantyre, Malawi. J Med Virol 2005, 77(4):522-527.

6. Tsugawa T, Numata-Kinoshita K, Honma S, Nakata S, Tatsumi M, Sakai Y, Natori K, Takeda N, Kobayashi S, Tsutsumi H: Virological, serological, and clinical features of an outbreak of acute gastroenteritis due to recombinant genogroup II norovirus in an infant home. J Clin Microbio/ 2006, 44(1):177-182.

7. Ambert-Balay K, Bon F, Le Guyader F, Pothier P, Kohli E: Characterization of new recombinant noroviruses. J Clin Microbiol 2005, 43(10):5179-5186.

8. Medici MC, Martinelli M, Abelli LA, Ruggeri FM, Di Bartolo I, Arcangeletti MC, Pinardi F, De Conto F, Izzi G, Bernasconi S, Chezzi C, Dettori G: Molecular epidemiology of norovirus infections in sporadic cases of viral gastroenteritis among children in Northern Italy. J Med Virol 2006, 78(11):1486-1492.

9. Matsui SM, Greenberg HB: Immunity to calicivirus infection. $J$ Infect Dis 2000, 181:S331-S335.

10. Lindesmith LC, Donaldson EF, Lobue AD, Cannon JL, Zheng DP, Vinje J, Baric RS: Mechanisms of Gll.4 norovirus persistence in human populations. PLOS Med 2008, 5(2):e31.

11. Lopman B, Vennema H, Kohli E, Pothier P, Sanchez A, Negredo A, Buesa J, Schreier E, Reacher M, Brown D, Gray J, Iturriza M, Gallimore C, Bottiger B, Hedlund KO, Torvén M, von Bonsdorff CH, Maunula L, Poljsak-Prijatelj M, Zimsek J, Reuter G, Szücs G, Melegh B, Svennson L, van Duijnhoven Y, Koopmans M: Increase in viral gastroenteritis outbreaks in Europe and epidemic spread of new norovirus variant. Lancet 2004, 363(9410):682-688.

12. Takkinen J: Recent norovirus outbreaks on river and seagoing cruise ships in Europe. Euro Surveill 2006, 11(6):E060615.2.

13. Pang XL, Preiksaitis JK, Wong S, Li V, Lee BE: Influence of novel norovirus Gll.4 variants on gastroenteritis outbreak dynamics in Alberta and the Northern Territories, Canada between 2000 and 2008. PLoS One 2010, 5(7):e11599

14. Park K, Baek K, Kim D, Kwon K, Bing S, Park J, Nam H, Lee S, Choi Y: Evaluation of a new immunochromatographic assay kit for the rapid detection of norovirus in fecal specimens. Ann Lab Med 2012, 32:79-81.
15. Park KS, Jeong HS, Baek KA, Lee CG, Park SM, Park JS, Choi YJ, Choi HJ, Cheon DS: Genetic analysis of norovirus Gll.4 variants circulating in Korea in 2008. Arch Virol 2010, 155(5):635-641.

16. Zheng DP, Ando T, Fankhauser RL, Beard RS, Glass RI, Monroe SS: Norovirus classification and proposed strain nomenclature. Virology 2006, 346(2):312-323.

17. Thompson JD, Higgins DG, Gibson TJ: Clustal W: improving the sensitivity of progressive multiple sequence alignment through sequence weighting, position-specific gap penalties and weight matrix choice. Nucleic Acids Res 1994, 22(22):4673-4680.

18. Saitou N, Nei M: The neighbor-joining method: a new method for reconstructing phylogenetic trees. Mol Biol Evol 1987, 4(4):406-425.

19. Tamura K, Dudley J, Nei M, Kumar S: MEGA4: Molecular Evolutionary Genetics Analysis (MEGA) software version 4.0. Mol Biol Evol 2007. 24(8):1596-1599

20. Bok K, Abente EJ, Realpe-Quintero M, Mitra T, Sosnovtsev SV, Kapikian AZ, Green KY: Evolutionary dynamics of Gll.4 noroviruses over a 34-year period. J Virol 2009, 83(22):11890-11901.

21. Schmid D, Lederer I, Pichler AM, Berghold C, Schreier E, Allerberger F: An outbreak of norovirus infection affecting an Austrian nursing home and a hospital. Wien Klin Wochenschr 2005, 117(23-24):802-808.

22. Marshall JA, Dimitraidis A, Wright PJ: Molecular and epidemiological features of norovirus-associated gastroenteritis outbreaks in Victoria, Australia in 2001. J Med Virol 2005, 75(2):321-331.

23. Widdowson MA, Cramer EH, Hadley L, Bresee JS, Beard RS, Bulens SN, Charles M, Chege W, Isakbaeva E, Wright JG, Mintz E, Forney D, Massey J, Glass RI, Monroe SS: Outbreaks of acute gastroenteritis on cruise ships and on land: identification of a predominant circulating strain of norovirus-United States, 2002. J Infect Dis 2004, 190(1):27-36.

24. Bull RA, Tu ET, Mclver CJ, Rawlinson WD, White PA: Emergence of a new norovirus genotype II.4 variant associated with global outbreaks of gastroenteritis. J Clin Microbiol 2006, 44(2):327-333.

25. Siebenga JJ, Vennema $H$, Zheng DP, Vinjé J, Lee BE, Pang XL, Ho EC, Lim W Choudekar A, Broor S, Halperin T, Rasool NB, Hewitt J, Greening GE, Jin M, Duan Z, Lucero Y, O'Ryan M, Hoehne M, Schreier E, Ratcliff RM, White PA, Iritani N, Reuter G, Koopmans M: Norovirus illness is a global problem: emergence and spread of norovirus Gll.4 variants, 2001-2007. J Infect Dis 2009, 200(5):802-12.

26. Chhabra P, Dhongade RK, Kalrao VR, Bavdekar AR, Chitambar SD: Epidemiological, clinical, and molecular features of norovirus infections in western India. J Med Virol 2009, 81:922-932.

27. Inouye S, Yamashita K, Yamadera S, Yoshikawa M, Kato N, Okabe N Surveillance of viral gastroenteritis in Japan: pediatric cases and outbreak incidents. J Infect Dis 2000, 181(2):S270-S274.

28. Liu C, Grillner L, Jonsson K, Linde A, Shen K, Lindell AT, Wirgart BZ, Johansen $\mathrm{K}$ : Identification of viral agents associated with diarrhea in young children during a winter season in Beijing, China. J Clin Virol 2006, 35(1):69-72.

29. Tu ET, Bull RA, Greening GE, Hewitt J, Lyon MJ, Marshall JA, Mclver CJ, Rawlinson WD, White PA: Epidemics of gastroenteritis during 2006 were associated with the spread of norovirus Gll.4 variants 2006a and 2006b. Clin Infect Dis 2008, 46(3):413-420.

30. Drake JW: Rates of spontaneous mutation among RNA viruses. Proc Natl Acad Sci USA 1993, 90(9):4171-4175.

doi:10.1186/1743-422X-9-29

Cite this article as: Park et al:: Updates on the genetic variations of Norovirus in sporadic gastroenteritis in Chungnam Korea, 2009-2010. Virology Journal 2012 9:29. 